\title{
The Variation of Several Biological Characteristics of the Chub, Squalius cephalus (L., 1758), in the Orenler Dam Lake, Northwest Anatolia, Turkey
}

\author{
Sait BULUT ${ }^{1}$, Ramazan MERT ${ }^{2 *}$, Muhsin KONUK ${ }^{1}$, Beklan ALGAN ${ }^{3}$, Ali ALAȘ ${ }^{4}$, Kemal SOLAK $^{5}$ \\ ${ }^{1}$ Afyonkocatepe University, Faculty of Science and Letters, Department of Biology, 03200, Afyonkarahisar, Turkey \\ ${ }^{2}$ Nevşehir University, Faculty of Science and Letters, Department of Biology, 50300, Nevsehir, Turkey; rmert20@gmail.com (*orresponding author) \\ ${ }^{3}$ Afyonkocatepe University, Institute of Science and Tecnology, TR-03200, Afyonkarahisar, Turkey \\ ${ }^{4}$ Necmettin Erbakan University, A.K. Education Faculty, Department of Biology, 42090, Konya, Turkey \\ ${ }^{5}$ Gazi University, Gazi Education Faculty, Department of Biology, TR-06500, Ankara, Turkey
}

\begin{abstract}
In the present study, several growth parameters of 338 Squalius cephalus (L., 1758) specimens collected from the Orenler dam lake (Turkey) between July 2005 and June 2006 were studied. The population comprised 50.74\% males, 46.29\% females, and 2.97\% males+females. In the examined samples, the age of females and males ranged from I to VII and I to VI, respectively. The fork length and weight of females were $14.7-38.0 \mathrm{~cm}$ and $40.68-27.0 \mathrm{~g}$, respectively; these values were 16.3-33.7 $\mathrm{cm}$ and $57.7-560.0 \mathrm{~g}$, respectively, for males. The age-length and age-weight relationships at time $t$ were calculated by the von Bertalanffy equation for females, and the following results were obtained: $L_{t}=37.12\left[1-\mathrm{e}^{-0.36(t-(-0.96))}\right], W_{t}=775.6\left[1-\mathrm{e}^{-0.36(t-(-0.96))}\right]^{3.27}, L_{t}=43.59\left[1-\mathrm{e}^{-0.3356(t-(-0.719))}\right]$, and $W_{t}=$ $1123.2\left[1-\mathrm{e}^{-0.3356(t-(-0.719))}\right]^{3.08}$. The calculated length-weight relationship was $W=0.36 L^{3.27}$ for females and $W=0.03356 L^{3.08}$ for males. The average condition factor was 1.412 for females and 1.284 for males. Consequently, in the Orenler dam lake, $S$. cephalus grows very well according to the study's results.
\end{abstract}

Keywords: Afyonkarahisar, chub, length-weight relationship, Squalius cephalus, von Bertalanffy

\section{Introduction}

The chub, Squalius cephalus is distributed in the whole of Europe, the Black Sea, the Azov Sea, the Caspian Sea, and Anatolian inland waters. It belongs to Cyprinidae family and prefers fresh, clean, and fast-flowing waters, as well as dam lakes (Kottelat and Freyhof, 2007). Efforts have been made to increase its population artificially in inland waters, such as dam lakes (Geldiay and Balik, 1999).

A number of studies on the chub's population in different parts of Turkey have been previously reported: Biology of the species in the Pinarbasi (İzmir) water spring (Geldiay and Balik, 1972), Bioecology of the species in the Kapulukaya dam lake (Gul, 1994), Bioecology of the species in the Kayabogazi dam lake in Kutahya (Alas, 1998), Some population characteristics of the species in Aksehir Lake (Altindag, 1996), Age, growth, and sex distribution of the species in the Topcam dam lake (Sasi and Balik, 2003), Growth characteristics of the species in the Sir dam lake (Kara and Solak, 2004), Age, growth, and reproduction characteristics of the species in the Ikizcetepeler dam lake (Koc et al., 2004), Growth, development, and mortality rates in the Almus dam lake (Karatas and Can, 2005), Changes in growth characteristics of the species in the Gelingullu dam lake (Kirankaya and Ekmekci, 2007) and
Biological characteristics of the species in Karasu River (Sen and Saygin, 2008).

Climatic, geographic, and ecological conditions affect the growth and reproductive features of living creatures differently. The Orenler dam lake contains fish that provide a large proportion of the protein supply for the region (Northwest Anatolia, Turkey). Despite its economic importance, few studies have focused on various aspects of the biology of the $S$. cephalus in the region (Karacali, 2007; Kurupinar and Ozturk, 2009; Yegen et al., 2009).

There is no study on the growth properties of the chub in the Orenler dam lake. Therefore, the aim of the study is to determine the age composition, sex ratio, length and weight growth, the length-weight relationship, and the condition factor of a chub sample and compared these with performance data obtained of the species from other regions.

\section{Materials and methods}

\section{Study area}

The Orenler dam lake is situated in the Sandikliborough of the Afyonkarahisar province, Turkey (38³6'20.98" N, $\left.30^{\circ} 13^{\prime} 46.74^{\prime \prime} \mathrm{E}\right)$, and was constructed on the Karadirek creek for irrigation purposes (Fig. 1) in 1993. It is also fed 
28

by the Ketenli, Nuh, Bilaci, Koru, and Kocadere creeks. Its coverage area is $3.23 \mathrm{~km}^{2}$, altitude is $1171 \mathrm{~m}$ above sea level, and depth is a maximum of $26 \mathrm{~m}$ (Fig. 1; Kurupinar and Ozturk, 2009).
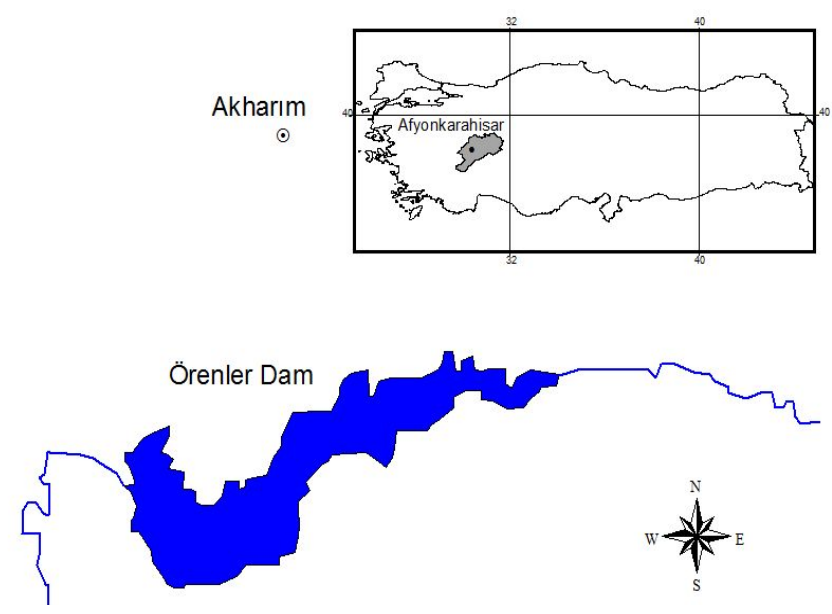

Fig. 1. Orenler dam lake, the studied site

\section{Sample collection}

For this study, 338 specimens were captured monthly from July 2005 to June 2006 using nets of 18-60 mm mesh size. Fish samples were transported to the laboratory for analyses of fork length (FL) to the nearest $0.1 \mathrm{~cm}$ and weight to the nearest $0.1 \mathrm{~g}$.

\section{Sex and age determination}

Sex was determined by macroscopic observation of the gonads. Age was determined from microscopic examination of scales. Ten to fifteen scales from the left side of the body between the lateral line and the dorsal fin were removed and dry-mounted between two slides for binocular microscopy (Lagler, 1966).

\section{Growth analysis}

The age-length relationship $\left(L_{t}=L_{\infty}\left[1-\mathrm{e}^{-k(t-t o)}\right]\right)$ and age-weight relationship $\left(W_{t}=W_{\infty}\left[1-\mathrm{e}^{-k(t-t)}\right]^{b}\right.$, were determined using the von Bertalanffy growth equations (Bertalanffy, 1938). The length-weight relationship was calculated using Le Cren's allometric growth formula: $W$ $=a \cdot L^{b}$ (1951). Condition coefficients were calculated for both sexes using the equation $K=\left(W / L^{3}\right) \times 100$ (Bagenal, 1978).

\section{Statistical analysis}

To compare growth and condition factor values of the same age group, the $T$-test was used and $p<0.05$ was accepted as the significant value (Duzgunes, 1975). Statistical analyses were carried out with the Statistical Package for the Social Sciences (SPSS) software.

\section{Results}

Age composition and sex ratio

Age and sex distribution data is summarized in Tab. 1 and Fig. 2. Age of the captured fish ranged between I and VII years, and the year II class was dominant. Because of selectivity of the nets, the 0 age group was not represented in the samples.

There were about $50.59 \%$ males and $46.45 \%$ females, and differences between sexes according to age were not significant $(p<0.05)$. The sex ratio (F:M) was 1:1.09.

Tab. 1. The age and gender distribution of $S$. cephalus in Orenler dam lake

\begin{tabular}{ccccccc}
\hline \multirow{2}{*}{ Age } & \multicolumn{2}{c}{ Female } & \multicolumn{2}{c}{ Male } & \multicolumn{2}{c}{ Female+Male } \\
\cline { 2 - 7 } & $\mathrm{N}$ & $\mathrm{N} \%$ & $\mathrm{~N}$ & $\mathrm{~N} \%$ & $\mathrm{~N}$ & $\mathrm{~N} \%$ \\
\hline I & - & - & - & - & 10 & 2.96 \\
II & 45 & 13.31 & 124 & 36.69 & 169 & 50.00 \\
III & 44 & 13.02 & 22 & 6.51 & 66 & 19.53 \\
IV & 31 & 9.17 & 12 & 3.55 & 43 & 12.72 \\
V & 16 & 4.73 & 8 & 2.37 & 24 & 7.10 \\
VI & 16 & 4.73 & 5 & 1.48 & 21 & 6.21 \\
VII & 5 & 1.48 & - & - & 5 & 1.48 \\
Total & 157 & 46.45 & 171 & 50.59 & 338 & 100 \\
\hline
\end{tabular}

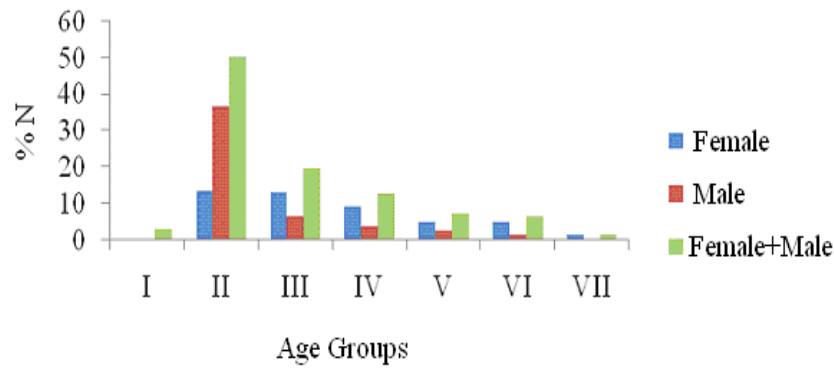

Fig. 2. The length distribution for $S$. cephalus in accordance to age and gender in Orenler dam lake

\section{Length-frequency distribution}

Of the 338 specimens measured, the FL of males ranged from 16.3 to $33.7 \mathrm{~cm}$; the range for females was higher $(14.7$ to $38.0 \mathrm{~cm}$ ) (Tab. 2). However, the difference between the mean FL of females and males for all years (except VI) was significant ( $p<0.05, T$-test).

\section{Growth}

Data on the mean FL and mean total weight for different ages in males, females, and males+females is summarized in Tab. 2 and 3. The number and percentage of males in year II were higher than females. But females were dominant for other years (III-VI).

Age-length and age-weight relationships of females and males are plotted in Fig. 3 and 4, respectively. Ageweight relationships are given in Tab. 4. Females grew 
Tab. 2. The fork length statistics for age and gender of $S$. cephalus Orenler dam lake

\begin{tabular}{|c|c|c|c|c|}
\hline Age & $\begin{array}{c}\text { Female } \\
\text { FL }(\mathrm{cm}) \pm S D \\
(\min -\max )\end{array}$ & $\begin{array}{c}\text { Male } \\
\text { FL }(\mathrm{cm}) \pm S D \\
(\min -\mathrm{max})\end{array}$ & $T$-test & $\begin{array}{c}\text { Female+Male } \\
\text { FL }(\mathrm{cm}) \pm S D \\
(\min -\max )\end{array}$ \\
\hline I & - & - & - & $\begin{array}{c}15.2 \pm 0.7 \\
(14.3-16.9)\end{array}$ \\
\hline II & $\begin{array}{c}19.6 \pm 1.3 \\
(14.7-21.4)\end{array}$ & $\begin{array}{c}19.3 \pm 1.0 \\
(16.3-22.5)\end{array}$ & $\begin{array}{c}p<0.05 \\
\text { significant }\end{array}$ & $\begin{array}{c}19.4 \pm 1.1 \\
(14.7-22.5)\end{array}$ \\
\hline III & $\begin{array}{c}25.7 \pm 2.4 \\
(19.4-28.9)\end{array}$ & $\begin{array}{c}21.1 \pm 0.8 \\
(19.6-23.0)\end{array}$ & $\begin{array}{c}\quad p<0.05 \\
\text { significant }\end{array}$ & $\begin{array}{c}24.1 \pm 2.9 \\
(19.4-28.9)\end{array}$ \\
\hline IV & $\begin{array}{c}28.4 \pm 1.1 \\
(25.0-30.0)\end{array}$ & $\begin{array}{c}24.1 \pm 2.8 \\
(18.5-27.9)\end{array}$ & $\begin{array}{c}p<0.05 \\
\text { significant }\end{array}$ & $\begin{array}{c}27.2 \pm 2.6 \\
(18.5-30.0)\end{array}$ \\
\hline $\mathrm{V}$ & $\begin{array}{c}30.1 \pm 0.8 \\
(28.5-31.6)\end{array}$ & $\begin{array}{c}26.6 \pm 2.6 \\
(22.5-29.3)\end{array}$ & $\begin{array}{c}p<0.05 \\
\text { significant }\end{array}$ & $\begin{array}{c}28.9 \pm 2.2 \\
(22.5-31.6)\end{array}$ \\
\hline VI & $\begin{array}{c}31.8 \pm 1.4 \\
(29.9-34.2)\end{array}$ & $\begin{array}{c}31.1 \pm 2.2 \\
(27.5-33.7)\end{array}$ & $\begin{array}{c}\quad p<0.05 \\
\text { insignificant }\end{array}$ & $\begin{array}{c}31.6 \pm 1.6 \\
(27.5-34.2)\end{array}$ \\
\hline VII & $\begin{array}{c}34.9 \pm 2.3 \\
(32.4-38.0) \\
\end{array}$ & - & $\begin{array}{lll}0 & 0\end{array}$ & $\begin{array}{c}34.9 \pm 2.2 \\
(32.4-38.0) \\
\end{array}$ \\
\hline
\end{tabular}

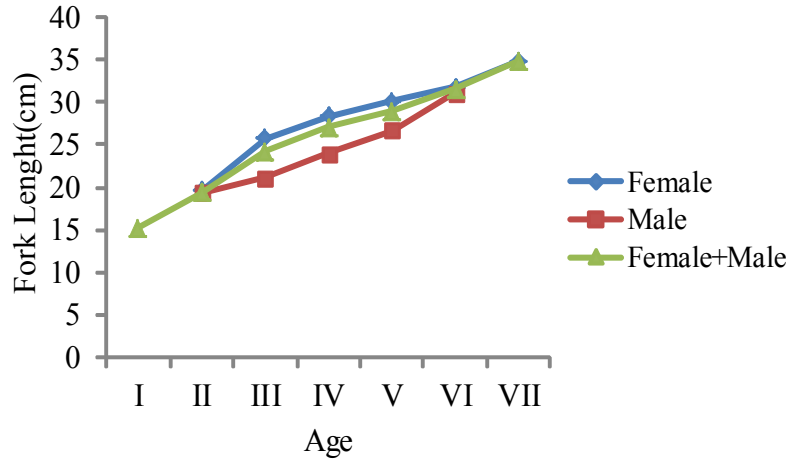

Fig. 3. The age-length relations for $S$. cephalus in Orenler dam lake

Tab. 3. The weight statistics for age and gender of $S$. cephalus in Orenler dam lake

\begin{tabular}{|c|c|c|c|c|}
\hline Age & $\begin{array}{c}\text { Female } \\
W(\mathrm{~g}) \pm S D \\
(\min -\max )\end{array}$ & $\begin{array}{c}\text { Male } \\
W(\mathrm{~g}) \pm S D \\
(\min -\max ) \\
\end{array}$ & T-test & $\begin{array}{c}\text { Female+Male } \\
W(\mathrm{~g}) \pm S D \\
(\min -\max )\end{array}$ \\
\hline I & - & - & - & $\begin{array}{c}42.6 \pm 4.4 \\
(36.5-50.7)\end{array}$ \\
\hline II & $\begin{array}{l}95.0 \pm 16.9 \\
(40.6-125)\end{array}$ & $\begin{array}{c}90.3 \pm 11.6 \\
(57.5-109.9)\end{array}$ & $\begin{array}{c}\quad p<0.05 \\
\text { significant }\end{array}$ & $\begin{array}{l}91.6 \pm 13.3 \\
(40.6-125)\end{array}$ \\
\hline III & $\begin{array}{c}241.0 \pm 62.6 \\
(105.2-328.1)\end{array}$ & $\begin{array}{c}120.5 \pm 9.1 \\
(110.4-140.4)\end{array}$ & $\begin{array}{c}p<0.05 \\
\text { significant }\end{array}$ & $\begin{array}{c}200.8 \pm 76.7 \\
(105.2-328.1)\end{array}$ \\
\hline IV & $\begin{array}{c}333.3 \pm 32.0 \\
(240.5-377.5)\end{array}$ & $\begin{array}{c}186.6 \pm 36.1 \\
(116.3-222.6)\end{array}$ & $\begin{array}{c}p<0.05 \\
\text { significant }\end{array}$ & $\begin{array}{c}292.4 \pm 74.2 \\
(116.3-377.5)\end{array}$ \\
\hline V & $\begin{array}{c}411.0 \pm 31.0 \\
(347-468)\end{array}$ & $\begin{array}{c}293.0 \pm 78.0 \\
(216.7-436.1)\end{array}$ & $\begin{array}{c}\quad p<0.05 \\
\text { significant }\end{array}$ & $\begin{array}{c}371.7 \pm 75.5 \\
(216.7-468)\end{array}$ \\
\hline VI & $\begin{array}{c}527.0 \pm 67.3 \\
(413.5-618.5)\end{array}$ & $\begin{array}{l}462.1 \pm 118.7 \\
(257.7-560.2)\end{array}$ & $\begin{array}{c}p<0.05 \\
\text { significant }\end{array}$ & $\begin{array}{c}511.5 \pm 83.7 \\
(257.7-618.5)\end{array}$ \\
\hline VII & $\begin{array}{l}724.1 \pm 65.1 \\
(654.5-827) \\
\end{array}$ & - & - & $\begin{array}{l}724.1 \pm 65.1 \\
(654.5-827) \\
\end{array}$ \\
\hline
\end{tabular}

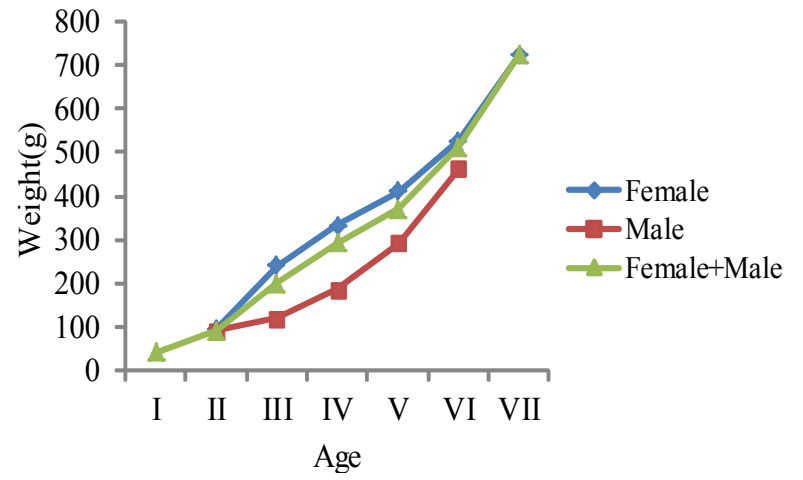

Fig. 4. The age-weight relations for $S$. cephalus in Orenler dam lake

Tab. 4. von Bertalanffy length increase parameters for $S$. cephalus in Orenler dam lake

\begin{tabular}{cccccc}
\hline Sex & $\mathrm{L} \infty$ & $\mathrm{t}_{\mathrm{o}}$ & $\mathrm{k}$ & $\mathrm{b}$ & Equations \\
\hline Female & 43.59 & -0.719 & -0.3356 & 3.2756 & $\mathrm{~L}_{\mathrm{t}}=43.59\left[1-\mathrm{e}^{-0.3356(\mathrm{t}+0.719))}\right]$ \\
$\begin{array}{c}\text { Male } \\
\text { Memale+ }\end{array}$ & 37.12 & -0.96 & -0.36 & 3.0807 & $\mathrm{~L}_{\mathrm{t}}=37.12\left[1-\mathrm{e}^{-0.36(\mathrm{t}+0.96))}\right]$ \\
$\begin{array}{c}\text { Male } \\
42.04\end{array}$ & -1.88 & -0.127 & 3.159 & $\mathrm{~L}_{\mathrm{t}}=42.04\left[1-\mathrm{e}^{-0.127(\mathrm{t}+1.88))}\right]$ \\
\hline
\end{tabular}

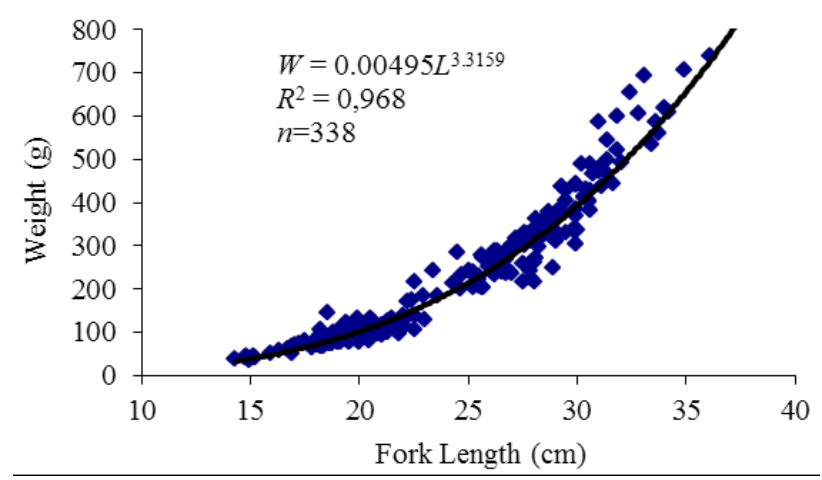

$\overline{\text { Fig. 5. Length-weight relationship of S. cephalus in Orenler dam }}$ lake

to a greater asymptotic $\left(L_{\infty}\right)$ length than males (Tab. 5). Females grew to a greater asymptotic $\left(W_{\infty}\right)$ weight than males and weighed more than males (Fig. 4). Differences between the sexes according to age group for total weight were statistically significant in all age groups $(p<0.05)$.

\section{Length-weight relationships}

According to the present findings the $b$ value for females was higher than that for males (Tab. 6). The lengthweight curves for males and females are plotted in Fig. 5.

\section{Condition factors}

The mean condition factor for females was higher than that for males, but the differences between sexes were not significant ( $p<0.05, T$-test; Tab. 7 and Fig. 6). 
30

Tab. 5. von Bertalanffy weight increase parameters for $S$. cephalus in Orenler dam lake

\begin{tabular}{cccccc}
\hline Sex & $\mathrm{W}_{\infty}$ & $\mathrm{t}_{\mathrm{o}}$ & $\mathrm{k}$ & $\mathrm{b}$ & Equations \\
\hline Female & 1123.2 & -0.719 & -0.3356 & 3.2756 & $\mathrm{~W}_{\mathrm{t}}: 1123.2\left[1-\mathrm{e}^{-0.3356(\mathrm{t}-(-0.719))}\right]^{3.2756}$ \\
Male & 775.6 & -0.96 & -0.36 & 3.0807 & $\mathrm{~W}_{\mathrm{t}}: 775.6\left[1-\mathrm{e}^{-0.36(\mathrm{t}-(-0.96))}\right]^{3.0807}$ \\
Female+Male & 1198.4 & -1.88 & -0.127 & 3.159 & $\mathrm{~W}_{\mathrm{r}}: 1198.4\left[1-\mathrm{e}^{-0.127(\mathrm{t}-(-1.88))}\right]^{3.3159}$ \\
\hline
\end{tabular}

Tab. 6. The equations of length-weight relation for $S$. cephalus in Orenler dam lake

\begin{tabular}{cccccc}
\hline Sex & $\mathrm{N}$ & $\mathrm{A}$ & $\mathrm{B}$ & Growth Equations & $\mathrm{r}$ \\
\hline Female & 157 & 0.0056 & 3.2756 & $\log \mathrm{W}=-2.2518+3.2756 \log \mathrm{L}$ & 0.963 \\
Male & 171 & 0.0100 & 3.0807 & $\log \mathrm{W}=-2+3.0807 \log \mathrm{L}$ & 0.906 \\
Female+Male & 338 & 0.0049 & 3.3159 & $\log \mathrm{W}=-2.3053+3.3159 \log \mathrm{L}$ & 0.968 \\
\hline
\end{tabular}

Tab. 7. Mean condition factor according to age and sex of S.cephalus in Orenler dam lake

\begin{tabular}{ccccc}
\hline Age & $\begin{array}{c}\text { Female } \\
\text { CF } \pm \text { SD } \\
(\text { min-max })\end{array}$ & $\begin{array}{c}\text { Male } \\
\text { CF } \pm \text { SD } \\
(\text { min-max })\end{array}$ & T-test & $\begin{array}{c}\text { Female+Male } \\
\text { CF } \pm S D \\
(\text { min-max })\end{array}$ \\
\hline I & - & - & - & $1.2112 \pm 0.0997$ \\
$(1.0503-1.3634)$ & $1.2454 \pm 0.1050$ \\
II & $1.2475 \pm 0.1231$ & $1.2441 \pm 0.1044$ & $p<0.05$ & $(0.9550-1.5004)$ \\
& $(1.0474-1.5004)$ & $(0.9550-1.4945)$ & insignificant & $1.3115 \pm 0.1707$ \\
III & $1.3928 \pm 0.1884$ & $1.2663 \pm 0.1421$ & $p<0.05$ & $(0.9437-1.9270)$ \\
IV & $(0.9917-1.9270)$ & $(0.9437-1.7417)$ & insignificant & $1.4329 \pm 0.2061$ \\
& $1.4572 \pm 1.1115$ & $1.3700 \pm 0.3497$ & $p<0.05$ & $(1.0249-1.6788)$ \\
V & $(1.1368-1.6324)$ & $(1.0249-1.6788)$ & insignificant & $1.5202 \pm 0.1677$ \\
& $1.5087 \pm 0.0968$ & $1.5433 \pm 0.2672$ & $p<0.05$ & $(1.2324-1.9024)$ \\
VI & $(1.4055-1.6609)$ & $(1.2324-1.9024)$ & insignificant & $1.6073 \pm 0.1580$ \\
& $1.6395 \pm 0.1473$ & $1.5042 \pm 0.1611$ & $p<0.05$ & $(1.2391-1.9690)$ \\
VII & $(1.4390-1.9690)$ & $(1.2391-1.6223)$ & insignificant & $1.7152 \pm 0.1922$ \\
\end{tabular}

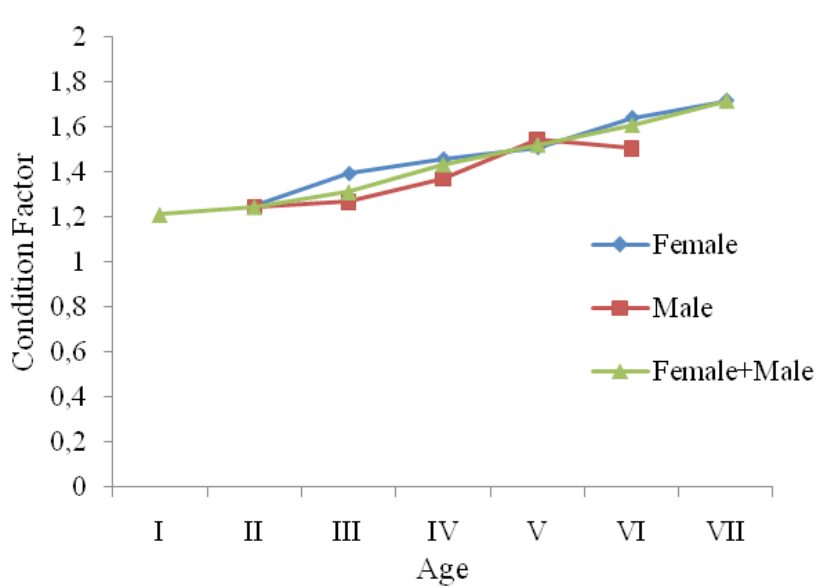

Fig. 6. Mean condition factor according to age and sex of $S$. cephalus

\section{Discussion}

In this research, a total of 338 specimens of $S$. cephalus from the Orenler dam lake were examined from July 2005 to June 2006. The age of the specimens ranged between years I and VII. Of the specimens $72.42 \%$ were between years I and III, indicating that the population comprised mostly young individuals.
According to the present findings, the $S$. cephalus population in the Orenler dam lake consisted of $50.59 \%$ males and $46.45 \%$ females. In this study, the sex ratio was 1:1.09 (F:M) and not significantly different from 1:1 ( $X^{2}$-test). Although the sex ratio in most of the species was close to 1 , this may vary from species to species, from one population to another of the same species, and year after year within the same population. At early life stages the ratio of males is higher, but at later stages the female ratio is higher (Nikolsky, 1963). Some early studies verify the present findings (Altindag, 1996; Balik et al., 2004; Ekmekci, 1996; Erdogan et al., 2002; Kalkan et al., 2005; Karatas, 1997; Koc et al., 2007; Oztas and Solak, 1988).

In this study, the year II group was dominant. Like the present findings, most of the samples were in the year II age group for Akşehir Lake, Muceldi Stream, and Isıkl Lake (Altindag, 1996; Balik et al., 2004; Oztas and Solak, 1988). On the other hand, findings at Kirmir Stream (Solak et al., 1995) and the Sariyar dam lake (Ekmekci, 1996) are different from the present findings.

The calculated $L_{\infty}$ values of females of the $S$. cephalus population were found to be greater than that of males in this study. The present results indicate that $L_{\infty}=43.59$ for females and $L_{\infty}=37.12$ for males, which are higher than the values reported by Altindag (1996), Erdogan et 
al. (2002), and Koc et al. (2007). On the other hand, the $L_{\infty}$ values are lower than the result of Unver and Tanyolac (1999). Differences noted in growth may be attributed to variations in habitat, temperature, and possibly differences in feeding habits (Yildirim et al., 2002). Geographic location and some environmental conditions, such as water temperature, organic matter, quality of food, date and time of capture, stomach fullness, disease, and parasite load, can also affect weight-at-age estimates (Bagenal and Tesch, 1978).

The length-weight relationship in fishes is affected by a number of factors, including season, habitat, gonad maturity, sex, diet and stomach fullness, health, and preservation techniques (Tesch, 1968). Results of the present study indicated that the $b$ value was 3.27 for females and 3.08 for males. So it could be concluded that the growth of $S$. cephalus in the Orenler dam lake is isometric, meaning that the shape does not change as the fish grows. In general, the value of $b$ lies between 2.5 and 4 and can vary as a result of changes in fish shape, season, age, and food availability (Ricker, 1979). In the present study, the value of $b$ remained within the expected range.

\section{Conclusions}

Consequently, othe present study provides some important information on the age and growth of S. cephalus that would be useful for fishery biologists to propose adequate regulations for sustainable fishery management and conservation of this economically important fish species in the Orenler dam lake. As no studies have been done on the age composition, sex ratio, length and weight growth, length-weight relationship, and condition factor of $S$. cephalus living in the Orenler dam lake, there is no comparison.

\section{References}

Alas A (1998). A stdudy on bio-ecology of Leuciscus cephalus (Linneaus, 1758) and Tinca tinca (L., 1758) inhabiting Kayaboğazi Dam Lake (Kütahya-Turkey). Gazi Univ Inst of Sci and Tech. Ankara, PhD Thesis, 152 p. (in Turkish).

Altındag A (1996). Some population characteristics, growth and condition of chub (Leuciscus cephalus, Linne 1758) in Aksehir Lake. Turk J Zool 20(Suppl):53-65.

Bagenal T (1978). Methods for assessment of fish production in freshwaters, Blackwell Scientific Publications. London, 365 p.

Bagenal T, Tesch FW (1978). Age and growth, 101-136 p. In: Bagenal T (Ed.). Methods for assessment of fish production in fresh water. I Handbook 3. Blackwell Scientific Publications, Oxford.

Balik S, Sari HM, Ustaoglu MR, Ilhan A (2004). Age and growth characteristics of chub (Leuciscus cephalus L., 1758) population in Işikli Lake, Çivril, Denizli, Turkey. Eu J Fish
Aqua Sci 21:257-262.

Duzgunes O (1975). Methods of statistics. Ankara Univ Press. Ankara, $179 \mathrm{p}$.

Ekmekci FG (1996). Growth and reproduction properties of chub (Leuciscus cephalus, Linnaeus, 1758) in Sariyar Dam Lake. Turk J Zool 20:95-106.

Erdogan O, Türkmen M, Yildirim A (2002). Studies on the age, growth and reproduction characteristics of the chub, Leuciscus cephalus orientalis, (Nordmann, 1840) in Karasu River, Turkey. Turk J Vet Anim Sci 26:983-991.

Geldiay R, Balik S (1999). Freshwater fishes of Turkey. Ege Univ Fac of Sci Public. No: 46, İzmir, 182-184 p. (in Turkish).

Geldiay R, Balik S (1972). Researches on the biology of the chub (Leuciscus cephalus L.), in Pınarbaşi spring water. Ege Univ Fac Sci, Bornova. İzmir, 139 p. (in Turkish).

Gul A (1994). A stdudy on bio-ecology of Stizostedion lucioperca (L., 1758) and Leuciscus cephalus (L., 1758) inhabiting Kapulukaya Dam Lake. Gazi Univ Inst of Sci and Tech. PhD Thesis. Ankara, 290 p. (in Turkish).

Kalkan E, Yilmaz M, Erdemli AU (2005). Some biological properties of the Leuciscus cephalus (L., 1758) population living in Karakaya Dam Lake in Malatya (Turkey). Turk J Vet Anim Sci 29:49-58.

Kara C, Solak K (2004). Growth properties of Chub (Leuciscus cephalus L., 1758) in Sir Dam Lake (Kahramanmaraş). KSU J Sci En 7(2):1-8 (in Turkish).

Karacali M (2007). Determination of seasonal variations of total fatty acids composition of Cyprinus carpio (L. 1758, Cyprinidae) living in Orenler Dam Lake. Afyon Kocatepe Univ Inst of Sci, Afyonkarahisar. MSc Thesis, 113 p. (in Turkish).

Karatas M, Can MF (2005). Growth, mortality and yield of chub (Leuciscus cephalus L., 1758) population in Almus Dam Lake. Turk J Biol Sci 5(6):729-733.

Karatas M (1997). A study on the reproduction biology of chub (Leuciscus cephalus) in Tozanli Stream (Almus-Tokat). Turk J Vet Anim Sci 21:513-516.

Kirankaya SG, Ekmekci FG (2007). Variations in growth properties of chub (Squalius cephalus, L., 1758) living in Gelingüllü Dam Lake. J Ins Sci Tech BAU 9(2):125-134 (in Turkish).

Koc HT, Erdogan Z, Tinkci M, Treer T (2007). Age, growth and reproductive characteristics of chub, Leuciscus cephalus (L., 1758) in Ikizcetepeler Dam Lake (Balikesir). Turk J Appl Ichthyol 23:19-24.

Kottelat M, FreyhofJ (2007). Handbook of European freshwater fishes. Kottelat, Cornol and Freyhof. Berlin, 646 p.

Kurupinar E , Ozturk MO (2009). A Study on the Helminth Fauna Linked to Seasonal Changes and Size of the Fish Host, Leuciscus cephalus L., from Lake Dam Orenler, Afyonkarahisar. Turk Soc Paras 33(3):248-253

Lagler KF (1966). Freshwater fishery biology. WMC. Brown Company, Iowa, $421 \mathrm{p}$. 
32

Le Cren ED (1951). The length-weight relationship and seasonal cyclein gonad weight and condition in perch, Perca fluviatilis. J Anim Ecol 20:201-219.

Nikolsky GV (1963). The ecology of fishes. Academic Press, London, $352 \mathrm{p}$.

Oztas H, Solak K (1988). The growth and sexual ratios of chub (Leuciscus cephalus L. 1758) living in the Muceldi Stream in the Eastern Anatolia. Doga Turk J Zool 12:262-271.

Ricker WE (1979). Growth rates and models, 786 p. In: Hoar WS, Randal DJ, Brett JR (Eds.). Fish physiology, 8. Academic Press, London, 786 p.

Solak K, Gul A, Yilmaz M (1995) A research on growing performations of Leuciscus cephalus (Linneaus, 1758) inhabiting Kirmir Stream (Ankara-Turkey). SDU J Water Prod Fish 4:49-62.

Sası H, Balik S (2003). Age, growth and sex ratio of chub (Leuciscus cephalus L., 1758) in Topçam Dam Lake. Eu J Fish Aqua Sci 20:503-515.

Sen F, Saygin F (2008). Biological properties of Chub (Leuciscus cephalus L., 1758) in Karasu Stream. J Anim Vet Advan $7(8): 1034-1037$.
Tesch FW (1968). Age and growth, 93-123 p. In: Bagenal TB (Ed.). Methods for Assessment of Fish Production in Freshwater. IBP Handbook No. 3, Blackwell, Oxford.

Von Bertalanffy L (1938). Quantitative laws in metabolism and growth. Q Rev Biol 32:217-213.

Yegen V, Balik S, Bostan H, Sari HM, Yagci A, Ilhan A (2009). Fish fauna of the dams and ponds in Afyonkarahisar, XV. National Water Products Symposium, 1-4 July, 119-120 p. (in Turkish).

Yildirim A, Erdogan O, Turkmen M (2002). On the age, growth and reproduction of the Barbel, Barbus plebejus (Steindachner, 1987) in the Oltu Stream of Coruh River (Artvin-Turkey). Turk J Zool 25:163-168.

Unver B, Tanyolac J (1999). Growth properties of Chub (Leuciscus cephalus L., 1758) in Tödürge Lake (Sivas). Doga Turk J Zool 23:257-270. 